\title{
Walnut (Juglans spp.) ecophysiology in response to environmental stresses and potential acclimation to climate change
}

\author{
Martin-Michel Gauthier • Douglass F. Jacobs
}

Received: 19 April 2011 / Accepted: 31 August 2011 /Published online: 5 October 2011

(C) INRA and Springer Science+Business Media B.V. 2011

\begin{abstract}
- Context Walnuts (Juglans spp.) are ecologically and commercially important trees, yet synthesis of past and current research findings on walnut ecophysiology is lacking, especially in terms of potential acclimation to climate change.

- Aims This study aims to (1) investigate walnut ecophysiology by comparing its attributes to associated deciduous angiosperms, (2) address potential acclimation of walnut to climate change, and (3) identify areas for prioritization in future research.

- Results There is considerable uncertainty regarding the magnitude of potential effects of climate change on walnut. Some studies tend to indicate walnut could be negatively impacted by climate change, while others do not. Walnut may be at a disadvantage due to its susceptibility to drought and frost injury in current growing regions given the projected increases in temperature and extreme climatic events. Other regions that are currently considered cold for walnut growth may see increased establishment and growth depending upon the rate of temperature increase and the frequency and severity of extreme climatic events.
\end{abstract}

Handling Editor: Erwin Dreyer

M.-M. Gauthier • D. F. Jacobs ( $\bowtie)$

Hardwood Tree Improvement and Regeneration Center,

Department of Forestry and Natural Resources, Purdue University,

715 W State St,

West Lafayette, IN 47907-2061, USA

e-mail: djacobs@purdue.edu

Present Address:

M.-M. Gauthier

Direction de la recherche forestière,

Ministère des Ressources naturelles et de la Faune du Québec,

2700 rue Einstein,

Québec, Québec G1P 3W8, Canada
- Conclusion Research investigating a combination of environmental factors, such as temperature, carbon dioxide, ozone, water, and nitrogen is needed to (1) better project climate change effects on walnut and (2) develop management strategies for walnut acclimation and adaptation to climate change.

Keywords Climate change Ecophysiology

Environmental stress $\cdot$ Juglans $\cdot$ Walnut

\section{Introduction}

The walnut genus (Juglans spp.) contains some of the most economically and ecologically valuable trees species in America, Europe, and Asia. Of the 20 species found worldwide, black walnut (Juglans nigra L.) and English walnut (Juglans regia L.) are the most abundant species of the genus and most commonly represented in the literature. Black walnut is dispersed throughout the central and eastern USA and is highly prized for its lumber. English walnut is also found scattered throughout Europe and Asia and is valued both for nut and lumber production (Hardin et al. 2001). In the western USA, English walnut and its associated hybrids are cultivated for nut production with an estimated crop value of US $\$ 700$ million (USDA 2009). Nuts are also an important food source for wildlife, such as squirrels (Sciurus spp.) (Smith and Follmer 1972). In recent years, a growing number of reports were published on physiological responses of walnut species to environmental factors, such as water, temperature, and nutrients. Many of these studies were conducted to address climate change issues, such as understanding decreased growth or survival due to the reduction in accumulated winter chill and increased freeze-thaw events for nut production in France 
(Améglio et al. 2004), the western USA (Baldocchi and Wong 2008; Luedeling et al. 2009a), and Southwest Asia (Luedeling et al. 2009b). Even studies not specifically aimed at investigating climate change can be useful in identifying physiological attributes of species that may become critical in relation to projected changes in climate, i.e., response to increased temperature or decreased precipitation. To our knowledge, there are no published reports that synthesize this body of work. Thus, the objectives of this review were to (1) investigate walnut ecophysiology and compare features to associated deciduous angiosperms, (2) address potential acclimation of walnut to climate change, and (3) identify areas for prioritization in future research. Insufficient scientific literature on the ecophysiology of other walnut species, such as butternut (Juglans cinerea L.), did not allow their inclusion in this review.

The literature reviewed on walnut stress physiology includes more than 100 articles that cover most of the research carried out in the last 35-60 years. The literature was grouped into four categories based on major plant functions: (1) carbon dynamics and photosynthesis, (2) nutrient functions, (3) acclimation to temperature, and (4) water relations. About half of all experiments studied English walnut or one of its associated hybrids; the other half investigated black walnut. Comparisons where often made with associated species, such as oak (Quercus spp.) and maple (Acer spp.), to contrast responses of species with different ecological and physiological attributes.

\section{Carbon dynamics and photosynthesis}

\subsection{Carbon dynamics}

Most of the literature on walnut $\mathrm{C}$ dynamics was carried out during the first or second year of development. Like oaks and other large-seeded species, walnut uses carbohydrates stored in the maternal seed to develop its taproot (Maillard et al. 1994a). For the first 3 weeks after sowing, the seedling is entirely heterotrophic, i.e., its growth depends exclusively on the seed's C reserves (Maillard et al. 1994a; Fig. 1a). Photosynthesis begins thereafter but is negligible until the second month of growth (Maillard et al. 1994a). In plantlets provided with a growing medium, autotrophy can be attained 8 days after transfer to a growth chamber (Chenevard et al. 1997), but seedlings need at least 40-50 days before they no longer depend on the maternal seed (Maillard et al. 1994a, b). Leaves are both a sink and a source of $\mathrm{C}$ during the second month, accounting for nearly $60 \%$ of all $\mathrm{C}$ in the plant (Fig. 1b). From days 32 to 48 after sowing, photosynthesis increases and leaves can allocate about $15 \%$ of labeled $\mathrm{C}$ to the stem. For the remainder of the second month, $\mathrm{C}$ produced by leaves is mostly allocated a

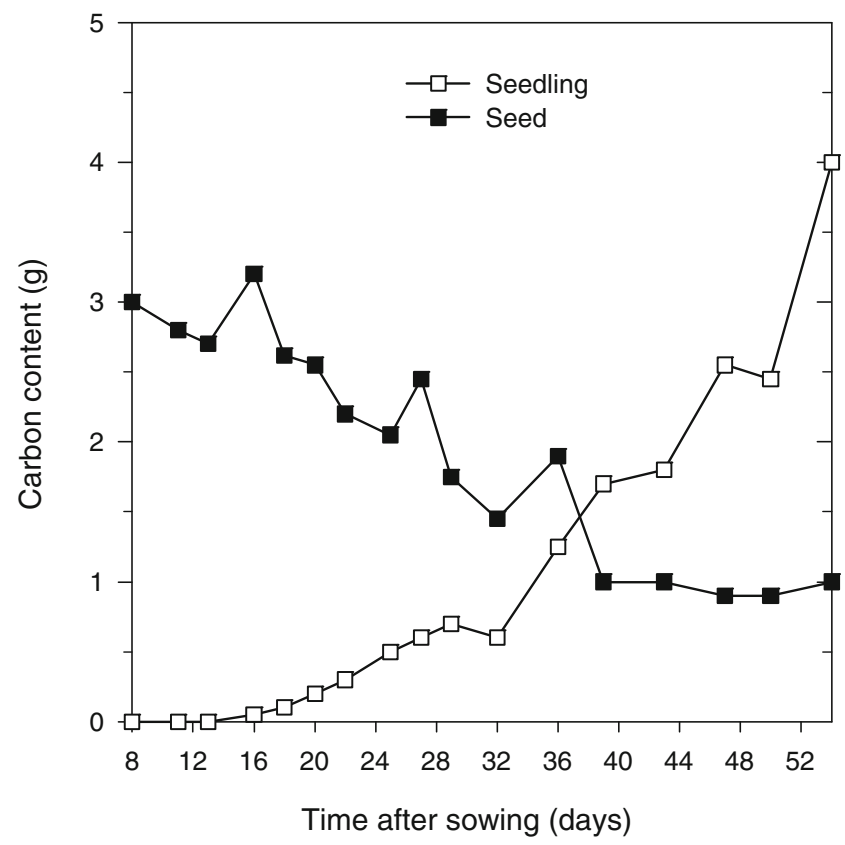

b

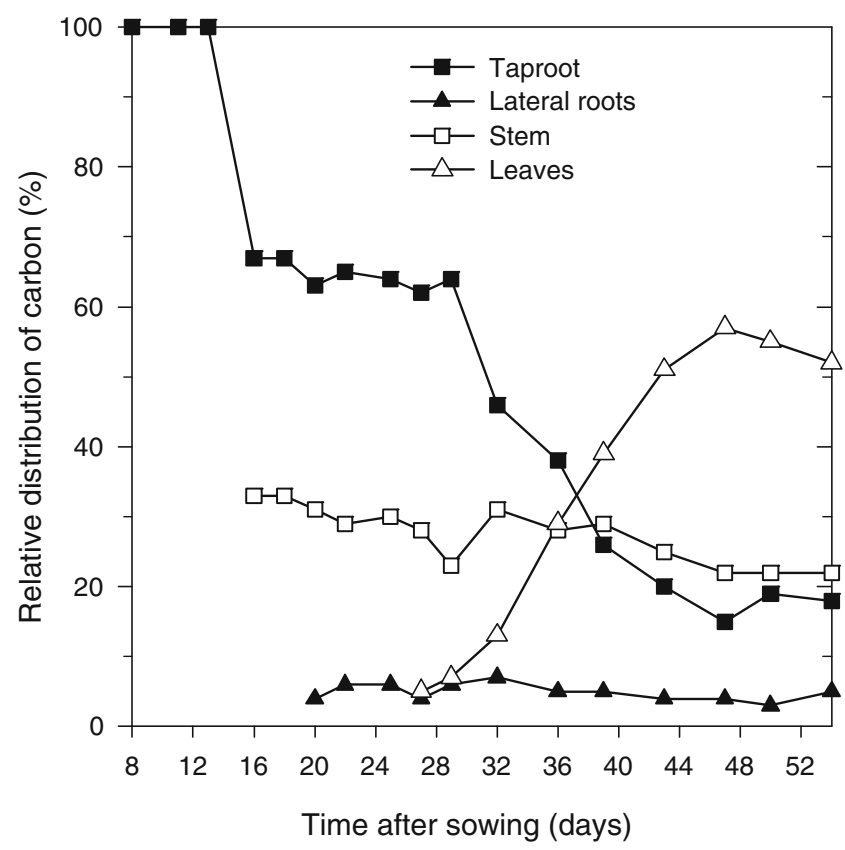

Fig. 1 Variation of carbon in an English walnut seedling (J. regia L.) and its maternal seed (a) and relative distribution of carbon in various organs of an English walnut seedling (b) under controlled conditions $\left(22^{\circ} \mathrm{C}, 12 \mathrm{~h}\right)$ during the first 2 months of development. Each value is the mean obtained from the combustion of dry matter of a set of five plant samples (Maillard et al. 1994b, by permission of Oxford University Press)

to the taproot and lateral roots (Maillard et al. 1994b). During the first growing season, most of the $\mathrm{C}$ fixed through photosynthesis is accumulated in the taproot $(\sim 90 \%)$ as starch, a large portion of which will serve as a 
source of carbohydrates for subsequent development (Lacointe 1989; Lacointe et al. 1993; Chenevard et al. 1994; Maillard et al. 1994a, b).

Published literature on walnut $\mathrm{C}$ dynamics in saplings or trees is less abundant, but research findings indicate remobilization can be substantial in this genus (Table 1). In this regard, walnut is similar to most tree species that accumulate large pools of non-structural carbohydrates (NSC), such as starch (Millard and Grelet 2010). In deciduous angiosperms, NSC levels are never fully depleted and are often at a maximum in late summer and early autumn (Millard and Grelet 2010). In 3-year-old English walnut, C accumulated as starch in the taproot in late summer and fall can be hydrolyzed to sugar in winter and remobilized by growing organs in spring (Frossard and Lacointe 1988; Lacointe et al. 1993). Lacointe et al. (1995) also reported that recent (up to 5 days old) $\mathrm{C}$ fluxes allocated toward respiration did not exceed $25 \%$ of total plant respiration as measured in August and October using ${ }^{14} \mathrm{CO}_{2}$ labeling in young English walnut trees. While changes in temperature and demand from sink organs are thought to be important causal mechanisms in walnut $\mathrm{C}$ remobilization, the relative importance of each mechanism is still uncertain (Lacointe 2000). A recent review by Millard and Grelet (2010) tends to suggest $\mathrm{C}$ remobilization in tree species is largely sink-driven.
Walnut's period of active photosynthesis and therefore potential annual $\mathrm{C}$ gain is restricted relative to associated species by its shorter period of full leaf out and determinate shoot growth habit. Walnut exhibits comparatively later ( 2 weeks) spring bud break (Lechowicz 1984) and earlier ( $\sim 1$ month) leaf fall senescence (Lucier and Hinckley 1982). As a result, walnut seedling growth is relatively rapid. In 1-year-old, field-grown black walnut, Carpenter and Hanover (1974) found that $73 \%$ of height growth occurred 1 month after bud break and $100 \%$ of stem growth and leaf area accretion occurred 2 months after bud break. Honeylocust (Gleditsia triacanthos L.), a shade-intolerant, associated species with an indeterminate growth habit displayed much slower growth compared to walnut: $60 \%$ of height growth, $50 \%$ of stem growth, and $68 \%$ of leaf area accretion occurred during the same time period. When the period of active photosynthesis is not taken into account, black walnut height growth is generally slower than yellow-poplar (Liriodendron tulipifera L.) or white ash (Fraxinus americana L.) but higher than oak species on good sites (Williams 1990). Some studies reported English walnut root and shoot growth occurred simultaneously during the first year (Frossard et al. 1989), while others did not (Maillard et al. 1994b). This periodicity can also change over time, as root development was found to occur after leaf and shoot growth during the second year (Frossard et al. 1989).

Table 1 Selected ecological and ecophysiological attributes of walnut (Juglans spp.) relative to associated deciduous angiosperms

\begin{tabular}{|c|c|c|c|}
\hline Ecological features & Relative level & Uncertainty & Selected references \\
\hline Shade tolerance & Low & Low & Baker 1948; Williams 1990 \\
\hline Growth rate & Average & Low & Carpenter and Hanover 1974; Williams 1990 \\
\hline Susceptibility to frost injury & High & Low & Fady et al. 2003; Poirier et al. 2010 \\
\hline Susceptibility to embolism & High & Low & Améglio et al. 2002; Bréda et al. 2006 \\
\hline Desiccation avoidance (susceptibility to drought) & High & Low & Davies and Kozlowski 1977; Hinckley et al. 1979 \\
\hline Flood avoidance (susceptibility to flooding) & High & High & Mapelli et al. 1997; Dudek et al. 1998 \\
\hline Rooting depth & High & Low & Pallardy and Rhoads 1993; Williams 1990 \\
\hline Nutrient requirements & High & Low & $\begin{array}{l}\text { Thompson and McComb 1962; Schlesinger and } \\
\text { Funk } 1977\end{array}$ \\
\hline Ecophysiological features & Relative level & Uncertainty & Selected references \\
\hline $\mathrm{C}$ and $\mathrm{N}$ accumulation and remobilization & Average & Low & $\begin{array}{l}\text { Lacointe 1989; Maillard et al. 1994a, b; Millard } \\
\text { and Grelet } 2010\end{array}$ \\
\hline Period of active photosynthesis and potential $\mathrm{C}$ gain & Low & Low & Lechowicz 1984; Lucier and Hinckley 1982 \\
\hline Capacity for photosynthesis $\left(A, A_{\max }\right)$ and respiration $\left(R_{\mathrm{d}}\right)$ & High & Low & Piel et al. 2002; Gauthier and Jacobs 2010 \\
\hline Capacity for light acclimation & Average & Low & Dean et al. 1982; Frak et al. 2001 \\
\hline Capacity to sustain repeated freeze-thaw events & Low & Low & Améglio et al. 2001c, 2002 \\
\hline Temperature inducing photoinhibition & Average & High & Dreyer et al. 2001 \\
\hline Stomatal sensitivity to humidity & High & Low & Ni and Pallardy 1990, 1992 \\
\hline Capacity for leaf abscission & High & Low & Ni and Pallardy 1991; Tyree et al. 1993 \\
\hline Response to elevated $\mathrm{CO}_{2}$ & High & High & Tinus 1976; Maillard et al. 1999 \\
\hline Response to elevated $\mathrm{O}_{3}$ & Unknown & High & None \\
\hline
\end{tabular}

Uncertainty is based on the number of studies conducted on the subject and the level of agreement among them 


\subsection{Photosynthetic capacity and acclimation}

Walnut has long been considered intolerant of shade (Baker 1948; Williams 1990; Hardin et al. 2001). Shade-intolerant species generally exhibit thicker leaves with lower quantum efficiency $\left(Q_{\mathrm{e}}\right.$, micromoles of $\mathrm{CO}_{2}$ per micromole photons) and higher light-saturated maximum photosynthesis $\left(A_{\max }\right.$, micromoles of $\mathrm{CO}_{2}$ per square meter per second) compared to leaves of shade-tolerant species (Loach 1967; Kozlowski and Pallardy 1997). Black walnut can also carry out substantial rates of net photosynthesis $(A$, micromoles of $\mathrm{CO}_{2}$ per square meter per second) during the growing season past the sapling stage (Gauthier and Jacobs 2010). These acclimations reflect the fact that shade-intolerant species require high light conditions to develop, where investments in increased mesophyll thickness allow greater photosynthate production. Findings from Dean et al. (1982) indicate that black walnut can carry out considerable $A$ under shaded conditions for short periods of time at the juvenile stage. In contrast to walnut, shade-tolerant species such as sugar maple (Acer saccharum Marsh.) develop thinner leaves that capture light more efficiently (higher $Q_{\mathrm{e}}$ ) and initiate $A$ at lower light levels $\left(\sim 0-200 \mu \mathrm{mol}\right.$ photons $\left.\mathrm{m}^{-2} \mathrm{~s}^{-1}\right)$.

Like all plants (Niinemets 2007), walnut exhibits photosynthetic plasticity to light. Walnut's photosynthetic acclimation and distribution of leaf characteristics, such as leaf mass per unit area (LMA) and leaf $\mathrm{N}$ content per unit area $\left(N_{\mathrm{a}}\right)$, are influenced by light level, light quality (red/far red ratio), and light source (Le Roux et al. 1999a; Green and Kruger 2001; Frak et al. 2002a, 2005; Rosati et al. 2004). Walnut's crown architecture varies according to the light environment to maximize $\mathrm{C}$ gain (Le Roux et al. 1999b, 2001; Sinoquet et al. 2001). For example, sun leaves of English walnut were found to have greater $A_{\max }$, stomatal conductance $(g)$, LMA, $N_{\mathrm{a}}$, and lower dark respiration $\left(R_{\mathrm{d}}\right.$, micromoles of $\mathrm{CO}_{2}$ per square meter per second) compared to shade leaves of the same species (Piel et al. 2002). Within the crown of a 20-year-old English walnut tree, LMA was shown to vary from 50 to $150 \mathrm{gm}^{-2}$ and $N_{\mathrm{a}}$ varied from 1 to $3 \mathrm{gm}^{-2}$ along a south-north horizontal transect (Le Roux et al. 1999b). The highest values were located on the southern edge and at the top of the canopy. A similar study also found spatial variation in leaf ${ }^{13} \mathrm{C}$ isotope composition ( $\sim 25-30 \%$ ) in the crown of an isolated English walnut tree (Le Roux et al. 2001).

The amount of time required for walnut to acclimate to changing light conditions increases with leaf age (Frak et al. 2001) and plant development stage (Gauthier and Jacobs 2009). Transferring 1-year-old English walnut hybrids from low light ( $10 \%$ incident radiation) to high light $(90 \%$ incident radiation) environments increased photosynthetic capacity by $25-45 \%$ within 20 days (Frak et al. 2001). Seedlings exhibited weak photosynthetic acclimation when transferred 91 days after bud burst in 1 year but were able to acclimate when transferred 58 days after bud burst in the next year (Frak et al. 2001). Acclimations were mainly due to changes in leaf $N_{\mathrm{a}}$ and leaf $\mathrm{N}$ partitioning among photosynthetic functions, such as carboxylation, bioenergetics, and light capture. Similar experiments conducted with northern red oak (Quercus rubra L.) and sugar maple at the seedling stage showed that time required for photosynthetic acclimation was comparable to results from Frak et al. (2001), despite species differences in shade tolerance (Naidu and DeLucia 1997). These findings also highlight the importance of $\mathrm{N}$ in walnut's photosynthetic acclimation to light. Acclimation to increased light may take longer (1 year) in black walnut trees past the sapling stage (Gauthier and Jacobs 2009).

Walnut's photosynthetic capacity and acclimation response to elevated $\mathrm{CO}_{2}$ and $\mathrm{O}_{3}$ is still poorly documented (Tinus 1976; Maillard et al. 1999). A five-fold increase in $\mathrm{CO}_{2}$, from 325 to $1500 \mu \mathrm{mol} \mathrm{mol}{ }^{-1}$, generated growth increases of $70 \%$ in dry mass of black walnut seedlings (Tinus 1976); the length of the measurement period and the age of the seedlings were not specified. Maillard et al. (1999) grew English walnuts from seed for 55 days under controlled chamber conditions to investigate $\mathrm{C}$ and $\mathrm{N}$ allocation patterns under two $\mathrm{CO}_{2}$ levels. Although not statistically confirmed, the $45 \%$ increase in $\mathrm{CO}_{2}$, from 550 to $800 \mu \mathrm{L} \mathrm{L}^{-1}$, doubled the $\mathrm{C}$ content of seedlings by the end of the measurement period (Fig. 2). Elevated $\mathrm{CO}_{2}$ also impacted $\mathrm{C}$ allocation by increasing the root/shoot ratio. In a synthesis of the literature, Wullschleger et al. (1995) compared relative growth responses of 73 tree species to a doubling of ambient $\mathrm{CO}_{2}$. Among

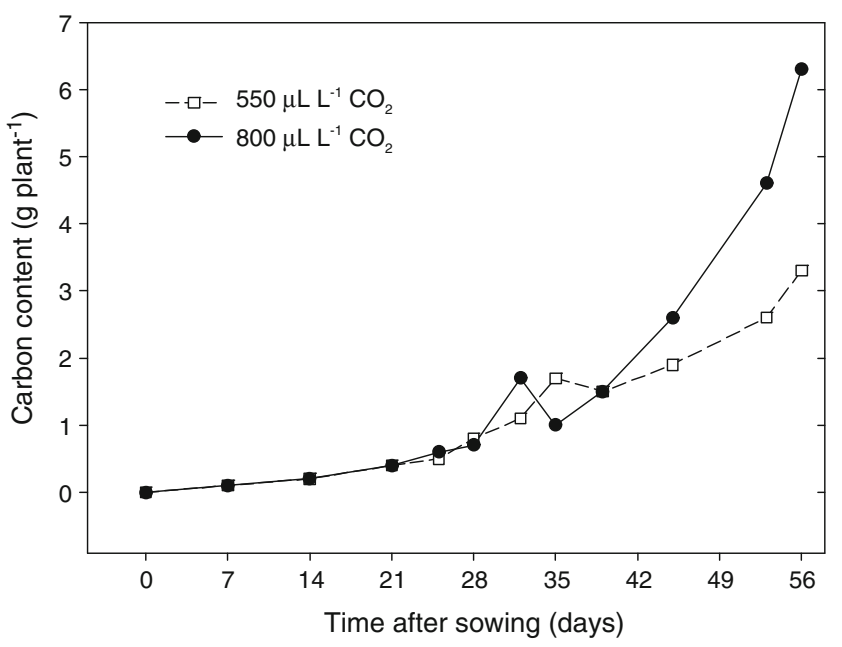

Fig. 2 Influence of elevated $\mathrm{CO}_{2}$, from 550 to $800 \mu \mathrm{L} \mathrm{L}^{-1}(46 \%$ increase), on the total carbon content of germinating English walnut (J. regia L.) seedlings. The end of seed $\mathrm{C}$ contribution occurred on day 35. Mean value was calculated from three replicates originating from a sample of five to ten seedlings. Source: Maillard et al. (1999), http://www.afs-journal.org/ 
all species studied, black walnut ranked 15 th in terms of relative increase in total plant dry mass $(46 \%)$ based on findings from Tinus (1976). Among temperate hardwoods, black walnut ranked third behind sugar maple (11th) and American beech (Fagus grandifolia Ehrh., 14th) but higher than northern red oak (25th) and white oak (Quercus alba L., 53rd). We did not find any literature investigating effects of elevated $\mathrm{O}_{3}$ in this genus.

In comparison to these studies, short-term ( 7 years) results from one of the free-air $\mathrm{CO}_{2}$ enrichment (FACE) experiments showed that $46-54 \%$ increases in atmospheric $\mathrm{CO}_{2}$ increased net primary productivity (NPP) of northern temperate hardwood forests of the USA by $25 \%$ to $60 \%$ compared to nontreated controls (King et al. 2005). Across four sites distributed in the USA and Europe, median gains in NPP from elevated $\mathrm{CO}_{2}\left(550 \mu \mathrm{mol} \mathrm{mol}{ }^{-1}\right)$ were calculated at $23 \%$ based on 10-year data from FACE experiments (Norby et al. 2005). More recent results showed declining $\mathrm{N}$ availability reduced these gains, thus stressing the importance of $\mathrm{N}$ on $\mathrm{C}$ gain and productivity at the forest scale (Norby et al. 2010). Results from King et al. (2005) also indicate that $34-45 \%$ increases in elevated $\mathrm{O}_{3}$ significantly reduced NPP of hardwood forests by $13-24 \%$ compared to nontreated controls. Thus, exceedances of $\mathrm{O}_{3}$ air quality standards could mitigate or offset biomass gains from elevated $\mathrm{CO}_{2}$ (Mohan et al. 2009) and exacerbate effects of increased temperatures and drought on forest growth in temperate hardwoods (McLaughlin et al. 2007a, b). Ozone effects may be due to reduced stomatal control of water loss. Drought alone could offset benefits associated with elevated $\mathrm{CO}_{2}$ as shown for sweetgum (Liquidambar styraciflua L.) (Warren et al. 2011).

Hence, walnut's photosynthetic capacity with regard to increased $\mathrm{CO}_{2}$ appears to be greater than average for deciduous angiosperms. Because of very limited data, however, substantial uncertainty remains regarding walnut's acclimation. Moreover, response to both $\mathrm{CO}_{2}$ and $\mathrm{O}_{3}$ cannot be determined given the lack of published data on $\mathrm{O}_{3}$.

\section{Nutrient functions}

\subsection{Nutrient requirements}

Compared to associated species, walnut has a relatively narrow range of soil conditions on which it grows well (Thompson and McComb 1962) and requires deep, fertile soils that have a high water holding capacity (Schlesinger and Funk 1977; Williams 1990). Growth and presence are also favored on south and southwest-facing slopes (Loacker et al. 2007) but reduced on shallow, drier, more infertile soils where the genetic potential for deep rooting is not fully realized. This indicates how important root system development is to Juglans species.

Research findings showed positive relationships between soil nutrient content and walnut development in terms of radial growth (Ponder 1998) and biomass production (Paschke et al. 1989). In 19-year-old black walnut, estimated above-ground dry biomass (kilograms) was strongly related to total nitrate $\left(\mathrm{NO}_{3}{ }^{-}, r^{2}=0.73\right)$ and total annual $\mathrm{NO}_{3}{ }^{-}$production $\left(r^{2}=0.41\right.$, Paschke et al. 1989). In 2-year-old black walnut rootstock, fertigation treatments increased leaf nutrient content by $18 \%$ to $86 \%$ for $\mathrm{N}$ compared with the nontreated control after one growing season (Salifu et al. 2006). Increases in P, from 33\% to $303 \%$, and $\mathrm{K}$, from $23 \%$ to $58 \%$, were also found in comparison with the control (Salifu et al. 2006). Two additional studies on fertilization of black walnut seedlings (Nicodemus et al. 2008a, b) indicate that a mixed N source is preferred over $\mathrm{NO}_{3}{ }^{-}$or $\mathrm{NH}_{4}{ }^{+}$alone to maximize productivity. Although walnut's nutrient requirements are high relative to other deciduous angiosperms, short-term response to fertilization can vary greatly depending upon soil conditions and type of fertilizer application (Jacobs and Seifert 2004). Black walnut's fertilization response may be lower compared to associated species such as yellow-poplar or white ash as shown for a 2-year outplanting experiment in the central USA (Jacobs et al. 2005).

\subsection{Nutrient allocation and remobilization}

As with other temperate hardwoods, $\mathrm{N}$ is essential to the early growth phase of walnut. Both $\mathrm{C}$ and $\mathrm{N}$ metabolism are related in this phase because the photosynthetic capacity of leaves depends on $\mathrm{N}$ content during growth (Figs. 1a, b and 3a, b). Similarly to C, walnut uses $\mathrm{N}$ stored in the maternal seed for taproot development (Fig. 3a). As the taproot develops from the seed in the first month of growth, $\mathrm{N}$ is allocated primarily to below-ground parts of seedlings, but rapidly developing aerial parts receive the majority of $\mathrm{N}$ during the second month of growth (Maillard et al. 1994a; Fig. 3b). Shortterm nutrient uptake by roots may also be coupled to $\mathrm{C}$ assimilation by leaves in older walnut seedlings. Delaire et al. (2005) measured short-term (9 days) effects of a 53\% increase in atmospheric $\left[\mathrm{CO}_{2}\right]$ on $\mathrm{CO}_{2}$ uptake by shoots and nutrient uptake by roots in 2-year-old black walnut hybrids. Results showed that $\mathrm{NO}_{3}^{-}, \mathrm{K}^{+}, \mathrm{Mg}^{2+}$, and $\mathrm{Ca}^{2+}$ uptake rates by roots were proportional to $\mathrm{CO}_{2}$ uptake rates by shoots during the study period, with $r^{2}$ values ranging from 0.73 to 0.80 . This coupling may be explained by nutrient acquisition through active transporter systems that require energy supplied by carbohydrates (Delaire et al. 2005). 
a

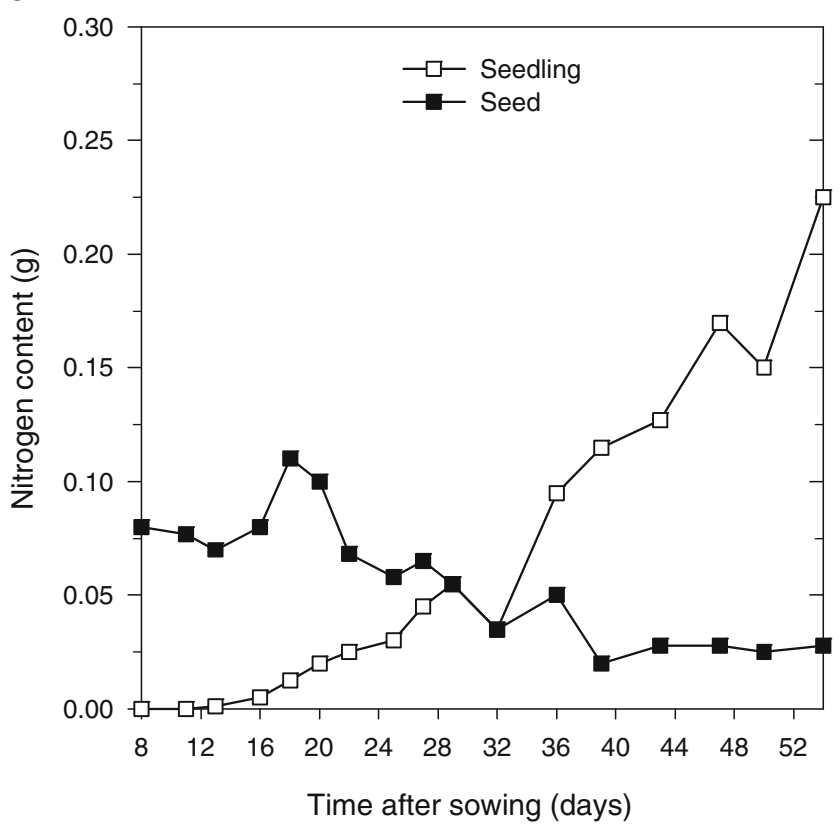

b

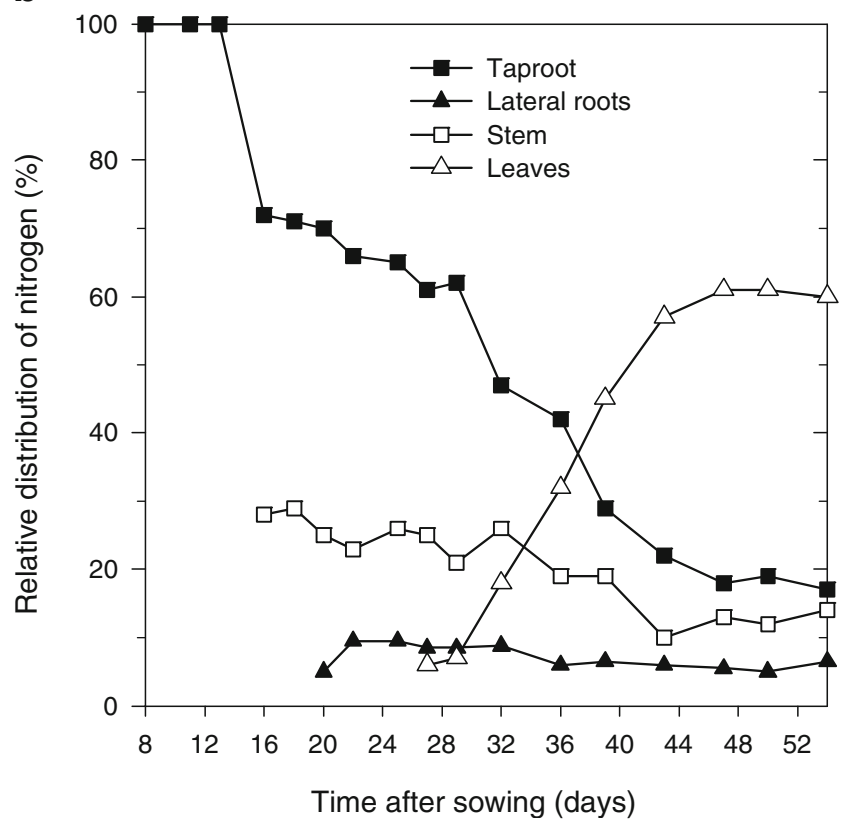

Fig. 3 Variation of nitrogen in an English walnut seedling (J. regia L.) and its maternal seed (a) and relative distribution of nitrogen in various organs of an English walnut seedling (b) under controlled conditions $\left(22^{\circ} \mathrm{C}, 12 \mathrm{~h}\right)$ during the first 2 months of development. Each value is the mean obtained from the combustion of dry matter of a set of five plant samples (Maillard et al. 1994b, by permission of Oxford University Press)

Retranslocation of stored nutrients is also important in meeting demand during periods of active growth, especially in terms of $\mathrm{N}$, as reported for walnut seedlings and mature trees (Deng et al. 1989; Weinbaum et al. 1994; Weinbaum and Van Kessel 1998; Frak et al. 2002b; Salifu et al. 2009).
Whereas $\mathrm{C}$ remobilization in tree species is largely sinkdriven, $\mathrm{N}$ remobilization is driven by the size of the storage pool (Millard and Grelet 2010). In walnut, N derived from storage accounted for about half of the xylem sap $\mathrm{N}$ throughout the leaf expansion period in mature English walnut hybrids growing in the western USA (Deng et al. 1989). In 1-year-old English walnut seedlings, spring remobilization of $\mathrm{N}$ stored during the previous year accounted for at least $54 \%$ of total $\mathrm{N}$ to new shoots (Frak et al. 2002b). Salifu et al. (2009) also demonstrated the importance of retranslocation in meeting early $\mathrm{N}$ demand of 1-year-old black walnut seedlings growing in sand culture. Weinbaum and Van Kessel (1998) reported that $60 \%$ of annual $\mathrm{N}$ demand of 9-year-old English walnut hybrids was derived from redistribution of $\mathrm{N}$ from internal pools. The remaining $40 \%$ was met by $\mathrm{N}$ influx from the soil/fertilizer pool. Results from Weinbaum and Van Kessel (1998) also indicate walnut hybrids stored the majority of soil and fertilizer $\mathrm{N}$ absorbed and used it for new growth within 2 years of uptake. Similar N remobilization to meet nutrient demand has been shown in several tree species and shrubs (Millard and Grelet 2010), including deciduous angiosperms such as northern red oak (Salifu et al. 2008) and sugar maple (Lennon et al. 1985; Goldfarb et al. 1990).

\section{Acclimation to temperature}

\subsection{Freezing tolerance and avoidance}

Plants generally survive subzero temperatures by exhibiting freezing tolerance, such as deep supercooling, or freezing avoidance, such as stem shrinkage. Walnut can exhibit both traits. Like many associated species including northern red oak, black walnut can display deep supercooling, i.e., freezing resistance near $-40^{\circ} \mathrm{C}$, across its native range when fully dormant (George et al. 1977). In addition to deep supercooling, walnut can also display stem shrinkage. Améglio et al. (2001a) showed trunks of 17-year-old English walnut orchard trees shrank up to $1300 \mu \mathrm{m}$ in diameter as air temperature fell to $-10^{\circ} \mathrm{C}$. Diameter expanded as temperature increased back up to $0^{\circ} \mathrm{C}$. Repeated freeze-thaw cycles at increasingly colder temperatures $\left(-2.5^{\circ} \mathrm{C},-5^{\circ} \mathrm{C},-7.5^{\circ} \mathrm{C},-10^{\circ} \mathrm{C}\right)$, carried out on excised segments of twigs from orchard trees, resulted in progressive loss of diameter up to $150 \mu \mathrm{m}$. Stem freezing occurred between $-4^{\circ} \mathrm{C}$ and $-8^{\circ} \mathrm{C}$ in English walnut, and similar stem freezing values $\left(-6^{\circ} \mathrm{C}\right.$ to $\left.-9^{\circ} \mathrm{C}\right)$ were reported in black walnut (Murray and Byrnes 1975). Pronounced shrinking of the living bark due to the formation of extracellular ice is an indication of freezing avoidance (Améglio et al. 2001b) and has been shown for other temperate deciduous angiosperms like white oak (Hinckley and Bruckerhoff 1975). 
Despite walnut's high freezing tolerance when fully dormant, spring frost injury appears to be important in English walnut, especially at the juvenile stage (Hemery et al. 2010; Poirier et al. 2010). Early bud break in English walnut can lead to apical bud death or shoot death during late spring frosts as shown in short-term juvenile field tests across five European countries (Fady et al. 2003). Development of freezing tolerance is thought to be related to soluble sugar accumulation (Poirier et al. 2010). In Slovenia, Crepinsek et al. (2009) analyzed the influence of increasing winter and spring air temperatures on bud break date in English walnut. Compared to the 1984-1990 period, mean air temperature from January to April increased by $0.9^{\circ} \mathrm{C}$ during the 2000-2006 period and bud break occurred 3-7 days earlier. By 2060, phenological models suggest bud break could be advanced up to 4 weeks, thus increasing frost hazard. Repeated freeze-thaw events can also lead to embolism, a phenomenon that has been the topic of many experiments with English walnut.

\subsection{Acclimation to freezing temperatures and embolism recovery}

Also termed cavitation, embolism is the formation of air bubbles in xylem vessels that can be caused by attainment of threshold negative hydrostatic pressures (tension) during drought and winter freezing events. Freeze-thaw cycles also cause embolism when air dissolved in xylem water is released from solution during ice formation. Walnuts are semi ring-porous species with large vessel diameters, which are of intermediate width compared to larger ring-porous species (northern red oak) and smaller diffuse-porous species (sugar maple). Ring-porous or semi ring-porous species are more susceptible to cavitation of xylem water columns during winter compared to diffuse-porous species or gymnosperms (Lechowicz 1984; Sperry et al. 1994). Tree species susceptible to water deficits are also more prone to cavitation (Tyree and Cochard 1996). Embolism effectively renders xylem conduits non conductive. This loss may be permanent or repair may occur so that hydraulic conductivity fully recovers (Améglio et al. 2002).

Repair in walnut species involves the development of positive hydrostatic pressures in roots and stems. In English walnut, root pressures were generated at temperatures above $15^{\circ} \mathrm{C}$ in autumn and spring, while stem pressures were involved at temperatures below $5^{\circ} \mathrm{C}$ in winter (Ewers et al. 2001). The greatest root pressures tend to occur in spring to help remove winter embolism that may have occurred in xylem vessels. Many other deciduous angiosperms such as European beech (Fagus sylvatica L.) develop positive xylem pressures in early spring, but not in winter (Cochard et al. 2001). Pressure apparently results from influx of carbohydrates into xylem from the symplast of neighboring tissues, a process that is correlated with seasonal changes in soil and air temperature in English walnut (Améglio et al. 2001c, 2004; Fig. 4). Sucrose demand by developing buds, leaves, and shoots provides a sink needed to move carbohydrates into the xylem (Decourteix et al. 2008; Bonhomme et al. 2010). This positive xylem pressure refills vessels, which regain hydraulic function (Améglio et al. 2002). Secondarily, new xylem is formed each spring, providing additional conduits for axial water flow. This mechanism is common to all plant species with secondary cambium (Cochard et al. 2001). Experiments by Alves et al. $(2004,2007)$ found that plasma membrane $\mathrm{H}^{+}$-ATPase plays an important role in the uptake of carbohydrates from xylem vessels during growth resumption in English walnut. Sucrose and hexose transporters ( $r S T U 1, J r H T 1, J r H T 2)$ involved in parenchyma cells of xylem vessels were also identified in English walnut (Decourteix et al. 2006, 2008).

\subsection{Heat stress}

In terms of heat stress, the critical leaf temperature inducing photochemistry damage appears to be remarkably similar $\left(\sim 47.0^{\circ} \mathrm{C}\right)$ among many deciduous angiosperms of western Europe (Dreyer et al. 2001). Using chlorophyll $a$ fluorescence measurements, trends showed values of maximal carboxylation rate $\left(V_{\text {cmax }}\right.$, micromoles of $\mathrm{CO}_{2}$ per square meter per second) and light-saturated electron transport $\left(J_{\max }\right.$, micromoles of electrons per square meter per second) at $25^{\circ} \mathrm{C}$ were the lowest in English walnut (63.6 and

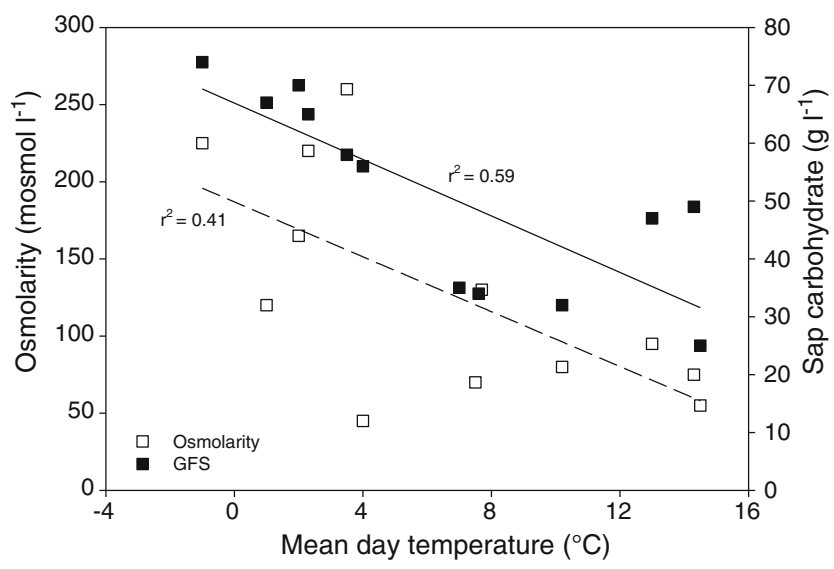

Fig. 4 Relationships between xylem sap osmolarity (milliosmoles of solute per liter of solution, $r^{2}=0.41$ ) or sap sugar concentration (GFS glucose + fructose + sucrose, $\left.r^{2}=0.59\right)$ and mean daily air temperature on 12 dates from November 1996 to March 1997. Xylem measurements were taken on excised, 1-year-old twigs of walnut (J. regia L. cv. Franquette scions on wild walnut rootstocks) from a 15 -year-old walnut orchard. Each value represents the mean of nine twigs. Mean air temperature was computed as the mean of the minimum and maximum air temperatures recorded for each date (Améglio et al. 2004, by permission of Oxford University Press) 
102.3 $\mu \mathrm{mol} \mathrm{m} \mathrm{m}^{-2} \mathrm{~s}^{-1}$, respectively) compared to other species including sycamore maple (Acer pseudoplatanus L.), pedunculate oak, and sessile oak (Quercus petraea Matt. Liebl.). In walnut, the highest $V_{\text {cmax }}$ values were attained at $36.6^{\circ} \mathrm{C}$, in the lower range compared to other species. This is in contrast to $J_{\max }$, where the temperature of $37.3^{\circ} \mathrm{C}$ was at the high end of the range. Species differences in $V_{\text {cmax }}$ could be due to intrinsic differences in Rubisco, while changes in $J_{\max }$ could be due to thylakoid membrane properties (Dreyer et al. 2001).

There can be considerable variation in both $V_{\text {cmax }}$ and $J_{\max }$ in walnut seedlings: Le Roux et al. (1999a) reported a range of $V_{\text {cmax }}$ from 20 to $69 \mu \mathrm{mol} \mathrm{m} \mathrm{s}^{-1}$ and $J_{\max }$ from 45 to $178 \mu \mathrm{mol} \mathrm{m} \mathrm{m}^{-2} \mathrm{~s}^{-1}$ in sun and shade leaves. Values reported by Dreyer et al. (2001) also compare favorably to mean $V_{\text {cmax }}\left(47.0 \mu m o l \mathrm{~m}^{-2} \mathrm{~s}^{-1}\right)$ and $J_{\max }$ (104.0 $\mu \mathrm{mol} \mathrm{m} \mathrm{m}^{-2} \mathrm{~s}^{-1}$ ) values reported for 19 temperate deciduous angiosperms by Wullschleger (1993).

\section{Water relations}

Plant water relations may be used to describe a plant's characteristics in terms of drought or flood tolerance. There is some evidence to suggest walnut may be flood intolerant (Mapelli et al. 1997; Dudek et al. 1998; Winter et al. 2009), but this aspect of water relations will not be covered in more detail due to the small number of experiments conducted on the subject compared to drought tolerance.

\subsection{Drought tolerance}

Based on Kramer's (1983) terminology, plants can be classified based on their capacity to avoid or tolerate drought. Drought avoidance refers to desert plants that avoid drought periods by completing their life cycle prior to the onset of drought. Hence, most other plants, including walnut, can be characterized in terms of drought tolerance. Tolerance is divided into desiccation avoidance and desiccation tolerance.

From the literature, black walnut has an extensively deep rooting habit (Williams 1990; Pallardy and Rhoads 1993) that allows it to maintain higher predawn leaf water potential $\left(\Psi_{\mathrm{pd}}\right)$ by extracting deep soil moisture unavailable to associated species like white oak (Hinckley et al. 1979; Martin et al. 1980; Lucier and Hinckley 1982; GinterWhitehouse et al. 1983). Root growth and number of growing roots, however, are still reduced by water deficits as reported by Kuhns et al. (1985).

Black walnut and English walnut also display high stomatal sensitivity to humidity, i.e., stomatal control of transpirational water loss in seedlings ( $\mathrm{Ni}$ and Pallardy 1990, 1992; Parker and Pallardy 1991) and mature trees
(Lucier and Hinckley 1982; Loewenstein and Pallardy 1998a; Daudet et al. 1999). Black walnut limits water loss in response to high vapor pressure gradients (Lucier and Hinckley 1982; Green 1993). Stomatal closure may regulate water tension in the leaf rachis xylem $\left(P_{\text {rachis }}\right)$ in English walnut (Cochard et al. 2002). Mechanisms by which stomata can sense changes in $P_{\text {rachis }}$ to regulate $g$ and prevent embolism are still unknown, but soil $\Psi$ or ABA production by roots was ruled out based on findings from Cochard et al. (2002). The signaling mechanism may reside in the leaf mesophyll itself. This is in contrast to findings from other studies with black walnut (Loewenstein and Pallardy 1998a, b, 2002) that suggest xylem sap [ABA] could act as a signal to regulate $g$ during periods of water deficits.

Contrary to most associated species, walnut is wellknown for exhibiting leaf abscission in periods of drought (Parker and Pallardy 1985a; Ni and Pallardy 1991; Pallardy and Rhoads 1993; Tyree et al. 1993). Ni and Pallardy (1991) found that 3-month-old black walnut seedlings placed in a growth chamber stopped $\mathrm{CO}_{2}$ assimilation and leaflets began senescing at $\Psi$ values of $-2.2 \mathrm{MPa}$ or less. Tyree et al. (1993) also reported leaf shedding at similar $\Psi$ values in 1-year-old English walnut seedlings subjected to drying cycles. Given walnut's relatively short period of active photosynthesis, leaf abscission reduces the amount of $\mathrm{C}$ that can be accumulated in fall and remobilized in spring.

The deep root system, stomatal sensitivity to humidity, and drought-induced leaf abscission habit suggest that walnut is comparatively sensitive to water deficits, with physiological responses being reflective of this sensitivity. Moreover, all three of these features are desiccation avoidance mechanisms that act to maintain high leaf water content. Failure to do so is reflected in comparatively large reductions in photosynthetic capacity (Davies and Kozlowski 1977; Hinckley et al. 1979) and likely drought-induced embolism (Cochard et al. 2002). Even in the absence of leaf abscission, drought may decrease the amount of accumulated $\mathrm{C}$ during late summer and fall, thus lowering winter frost resistance and embolism repair. Because walnut bud break occurs relatively late, winter embolism repair also serves a critical role in walnut's water relations by restoring hydraulic conductivity at bud break. This allows for rapid primary growth without prior need to build new secondary tissues. Without this repair mechanism, walnut's susceptibility to drought would increase and growth rate could be severely reduced.

To better illustrate walnut's desiccation avoidance, Davies and Kozlowski (1977) used a soil drying cycle to investigate effects of water deficits on 2- and 3-year-old potted seedlings of six woody angiosperms growing in controlled environments. As drought stress increased and leaf $\Psi$ reached $-2.5 \mathrm{MPa}$, relative rates of $A$ rapidly 
dropped near 0\% (Fig. 5). Compared to sugar maple and American elm (Ulmus americana L.), black walnut was the only species that did not recover from drought, exhibiting "leaf yellowing and senescence symptoms as soil water became limiting" (Davies and Kozlowski 1977). Black walnut was ranked as having the lowest ability to photosynthesize under drought stress compared to white oak, northern red oak, and sugar maple (Hinckley et al. 1979). Using electrolyte leakage measurements, Martin et al. (1987) showed that leaf desiccation tolerance acclimation was poorly developed in black walnut compared to northern red oak and white oak.

\subsection{Other leaf osmotic adjustments}

Walnut exhibits other leaf osmotic adjustments that can vary greatly among families (Parker and Pallardy 1985a, b). Such adjustments include increased water-use efficiency (WUE; micromoles of $\mathrm{CO}_{2}$ per mole per $\mathrm{H}_{2} \mathrm{O}$ ) and leaf hydraulic conductance ( $K_{\text {leaf }}$; millimoles of $\mathrm{H}_{2} \mathrm{O}$ per second per megapascal). These may also be regarded as desiccation avoidance mechanisms, although the relationship is not as evident as rooting habit, stomatal closure, or leaf abscission. Picon-Cochard et al. (2001) used labeling techniques to study competition of rye grass and drought on photosynthetic parameters of 3-month-old English walnut seedlings. Walnut displayed much higher WUE (41\%) than rye (Lolium perenne L.) grass when grown separately. Drought was found to increase WUE by nearly $40 \%$ in English walnut seedlings when growing with rye grass

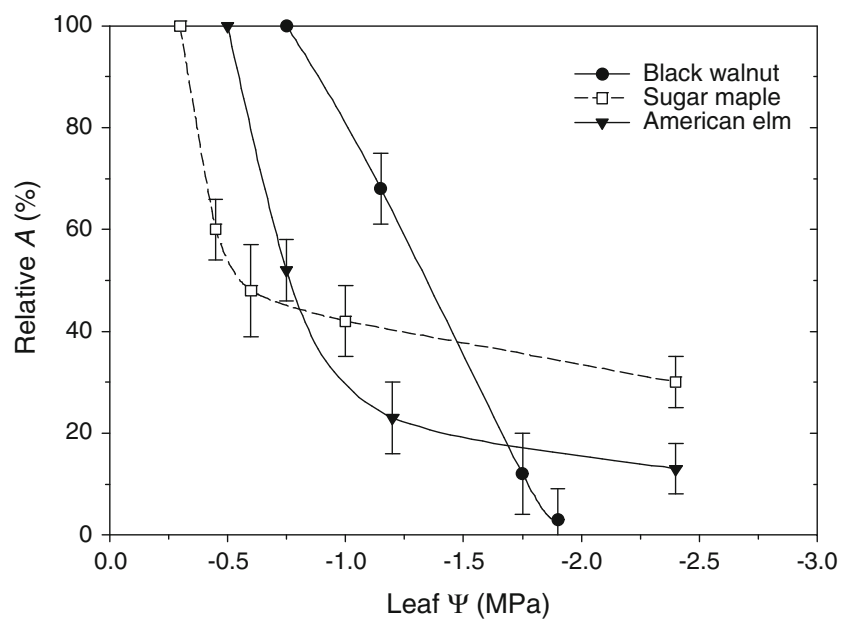

Fig. 5 Influence of drought as measured by leaf water potential ( $\Psi$, megapascals) on the relative net photosynthesis $(A$, in percent) of 3year-old black walnut (J. nigra L.) and sugar maple (A. saccharum Marsh.) seedlings and 2-year-old American elm (U. americana L.) seedlings. Potted plants were subjected to a soil drying cycle and compared to seedlings growing in unstressed environmental conditions. With kind permission from Davies and Kozlowski (1977) and Springer Science + Business Media, Fig. 2 competition, but not in the pure walnut treatment. During initial drought stress, several deciduous angiosperms can display transient increases in WUE, such as northern red oak and sugar maple (Ni and Pallardy 1991). Black walnut, however, can maintain higher WUE than most associated species until severe water deficits occur, eventually decreasing WUE (Ni and Pallardy 1991). Cochard et al. (2007) found that leaves from mature English walnut trees can quickly change $K_{\text {leaf }}$ in response to light and temperature. Furthermore, these changes can be explained by regulation of aquaporins ( $J r P I P 2,1$ and $J r P I P 2,2)$, proteins located in the plasma membrane that allow transport through cell membranes. Results indicate that water flow through walnut leaves under high light followed a symplastic pathway and was influenced by increases in the density of aquaporins in the cell membrane. In the dark, however, the apoplastic route was prevalent and influence of aquaporins was limited. Aquaporins are also involved in walnut embolism recovery (Sakr et al. 2003).

\section{Potential effects of climate change}

Regional climate change projections from the Intergovernmental Panel on Climate Change (IPCC) were used to describe potential changes in temperature and precipitation in the distribution areas of both species (Christensen et al. 2007). Changes refer to the difference between the 2080 2099 and 1980-1999 periods and were based on the IPCC's A1B scenario that describes the twenty-first century as a "world of very rapid economic growth, a global population that peaks in mid-century and rapid introduction of new and more efficient technologies" that are balanced between fossil and non-fossil energy resources (Nakicenovic et al. 2000). In North America and northern Europe, mean annual temperature and precipitation are expected to increase (Table 2). Moreover, extreme climatic events, such as storms, floods, and droughts, may occur more frequently and become more harmful in northern Europe (Lindner et al. 2010). For southern Europe and the Mediterranean, mean annual temperature is expected to rise while precipitation is expected to decrease (Table 2). Risk of summer drought is likely to increase in these regions (Christensen et al. 2007), including western Europe (Bréda et al. 2006). In terms of elevated $\mathrm{CO}_{2}$, concentrations are projected to increase to at least $486 \mu \mathrm{mol} \mathrm{mol}{ }^{-1}$ by 2100 compared to preindustrial values of $280 \mu \mathrm{mol} \mathrm{mol}{ }^{-1}$ (Nakicenovic et al. 2000).

This information, combined with many of the previously addressed topics, can provide insight on climate change impacts on walnut growth. This insight is especially relevant in wild or extensively managed areas where nutrient supply is limiting. The magnitude of change in 
temperature is much greater than potential changes in precipitation (Table 2). There are concerns that these conditions may increase evapotranspiration rates (Lemprière et al. 2008; Huntington et al. 2009) and make forest tree species more susceptible to drought. As such, walnut may be at a disadvantage due to its susceptibility to water deficits, especially where drought events are predicted to occur more frequently. In the central USA, water deficits early in the growing season may be the most important factor limiting growth of black walnut on upland sites (Dudek et al. 1998). This could be particularly important for establishment and growth of regeneration because research findings suggest seedlings may be more intolerant of drought than mature trees.

Walnut may also be more susceptible to late spring frost injury and embolism due to increased freeze-thaw events, as shown in the temperature section. Moreover, development of freezing tolerance and embolism recovery in walnut are both related to soluble sugar accumulation (Decourteix et al. 2008; Bonhomme et al. 2010; Poirier et al. 2010). Thus, an increase in summer drought or heat stress may also increase spring frost hazard due to a reduction in accumulated $\mathrm{C}$ and stored $\mathrm{N}$ during the previous growing season. Some of the lowest annual diameter growth rates reported in English walnut were associated with exceptionally cool temperatures in late spring and early summer (Winter et al. 2009). Certain walnut growing regions could be impacted according to current predictions of future climates, such as the western USA (Allen et al. 2010) and portions of Europe under Mediterranean and temperate continental climates (Lindner et al. 2010). There is already some modeling evidence suggesting climate change may lower chilling requirements in California, making walnut more vulnerable to frost-induced embolism in early spring (Baldocchi and Wong 2008) and pest attacks (Luedeling et al. 2011). Similarly, phenological models indicate that increasing spring temperatures may advance bud break by up to 4 weeks in central Europe, thus increasing spring frost hazard (Crepinsek et al. 2009).
There is also evidence suggesting walnut growth and distribution may remain stable or increase in the twentyfirst century. This evidence is based on larger-scale studies. For traditionally cold walnut growing regions with mean annual temperature of $7-8^{\circ} \mathrm{C}$, projected increases in temperature that provide milder winters may actually increase walnut establishment as reported for English walnut in inner Alpine valleys of Austria (Loacker et al. 2007). These findings indicate that areas that are currently considered cold for walnut growth may see increased establishment and growth depending upon the rate of temperature increase and the frequency and severity of extreme climatic events. Another large-scale study of 130 tree species in North America showed black walnut's climate-envelope area may not be drastically reduced by 2100 (McKenney et al. 2007). Under a scenario where populations can fully migrate into their future climate habitat, black walnut's distribution was projected to shift northward by $8.2^{\circ}$ latitude $(\sim 900 \mathrm{~km})$ compared to $6.4^{\circ}$ $(\sim 700 \mathrm{~km})$ for all species combined. This placed black walnut 15th out of 130 species in terms of northward shift but still behind several associated deciduous angiosperms: sugar maple, northern red oak, white ash, and white oak (McKenney et al. 2007). Under a scenario where populations survive only in areas that overlap their current range, black walnut's predicted northward shift was the same as the overall mean of $3.0^{\circ}(\sim 330 \mathrm{~km})$. The actual shift is likely to be found between these two extremes. In addition to these studies, productivity gains associated with increased atmospheric $\mathrm{CO}_{2}$ in walnut appear to be greater than average, but there are very few published results for walnut, combined with a lack of data on negative effects of elevated $\mathrm{O}_{3}$.

\section{Future research needs}

Overall, some studies tend to indicate walnut could be negatively impacted by climate change, while others do

Table 2 Median annual and seasonal (summer, winter) temperature and precipitation projections for various regions where walnuts occur

\begin{tabular}{|c|c|c|c|c|c|c|c|c|}
\hline \multirow[t]{2}{*}{ Species } & \multirow[t]{2}{*}{ Climate } & \multirow[t]{2}{*}{ Region } & \multicolumn{3}{|c|}{ Temperature $\left({ }^{\circ} \mathrm{C}\right)$} & \multicolumn{3}{|c|}{ Precipitation $(\%)$} \\
\hline & & & Sum & Win & Ann & Sum & Win & Ann \\
\hline \multirow{3}{*}{$\begin{array}{l}\text { Black walnut } \\
\text { (Juglans nigra) }\end{array}$} & Humid continental & Eastern North America & 3.3 & 3.8 & 3.6 & 1 & 11 & 7 \\
\hline & Humid subtropical & Central North America & 4.1 & 3.5 & 3.5 & -3 & 5 & 3 \\
\hline & Mediterranean & Western North America & 3.8 & 3.6 & 3.4 & -1 & 7 & 5 \\
\hline \multirow{2}{*}{$\begin{array}{l}\text { English walnut } \\
\text { (Juglans regia) }\end{array}$} & Temperate oceanic & Northern Europe & 2.7 & 4.3 & 3.2 & 2 & 15 & 9 \\
\hline & Temperate continental, Mediterranean & Southern Europe and the Mediterranean & 4.1 & 2.6 & 3.5 & -24 & -6 & -12 \\
\hline
\end{tabular}

Values represent the difference between the 2080-2099 and 1980-1999 periods. Full details of climate change scenario projections can be found in Christensen et al. (2007)

ann annual, sum summer, win winter 
not. There is also considerable uncertainty regarding the magnitude of potential climate change effects, from growth and development of individual trees to survival and distribution patterns of the genus. We identified a number of areas that could help address some of this uncertainty. Quantifying walnut's response to elevated $\mathrm{CO}_{2}$ and $\mathrm{O}_{3}$ would be essential to determine potential impacts on productivity. We found few experiments investigating the effects of heat stress, which may be critical to growth and survival under warmer temperatures and increased frequency of extreme climatic events. We believe that research investigating a combination of environmental factors (temperature, $\mathrm{CO}_{2}, \mathrm{O}_{3}, \mathrm{~N}$, water) would provide a better understanding of integrated stress response of walnut. In our view, patterns of $\mathrm{C}$ and $\mathrm{N}$ allocation and remobilization during periods of environmental stress warrant further investigation given the importance of these mechanisms. Additional research in these areas would help increase our understanding of the fundamental processes related to physiological acclimation to climate change.

Flooding responses have received little attention compared to the impacts of water deficits; more research is needed to elucidate flooding effects on ecophysiological processes of walnut and their subsequent impact on growth. Nutrient processes have been largely directed at N; experiments that examine other macronutrients that are essential for growth and survival, such as $\mathrm{P}$ and $\mathrm{K}$, would enhance depth in knowledge of walnut nutrient dynamics.

At a larger scale, we recommend investigations into walnut's natural distribution across a gradient of physiographic and climatic features, e.g., altitude, temperature, precipitation, drainage, soil fertility, slope, aspect. This would help connect ecophysiological responses with longterm forest development and stand dynamics.

Acknowledgments We thank Drs. J.A. Kershaw, Jr., Richard Meilan, and Phillip E. Pope for their comments on an earlier version of this manuscript. We appreciate comments and suggestions from the reviewers that helped improve the quality and synthesis of the manuscript.

Funding The Frederick M. van Eck Foundation of the Hardwood Tree Improvement and Regeneration Center and the Department of Forestry and Natural Resources at Purdue University provided financial support.

\section{References}

Allen CD, Macalady AK, Chenchouni H, Bachelet D, McDowell N, Vennetier M, Kitzberger T, Rigling A, Breshears DD, Hogg EH, Gonzalez P, Fensham R, Zhang Z, Castro J, Demidova N, Lim JH, Allard G, Running SW, Semerci A, Cobb N (2010) A global overview of drought and heat-induced tree mortality reveals emerging climate change risks for forests. For Ecol Manage 259:660-684

Alves G, Améglio T, Guilliot A, Fleurat-Lessard P, Lacointe A, Sakr S, Pétel G, Julien J-L (2004) Winter variation in xylem sap pH of walnut trees: involvement of plasma membrane $\mathrm{H}^{+}$-ATPase of vessel-associated cells. Tree Physiol 24:99-105

Alves G, Decourteix M, Fleurat-Lessard P, Sakr S, Bonhomme M, Améglio T, Lacointe A, Julien J-L, Pétel G, Guilliot A (2007) Spatial activity and expression of plasma membrane $\mathrm{H}^{+}$-ATPase in stem xylem of walnut during dormancy and growth resumption. Tree Physiol 27:1471-1480

Améglio T, Cochard H, Ewers FW (2001a) Stem diameter variations and cold hardiness in walnut trees. J Exp Bot 52:2135-2142

Améglio T, Cochard H, Lacointe A, Vandame M, Bodet C, Cruiziat P, Sauter J, Ewers F, Martignac M (2001b) Adaptation to cold temperature and response to freezing in walnut tree. Acta Hort 544:247-254

Améglio T, Ewers FW, Cochard H, Martignac M, Vandame M, Bodet C, Cruiziat P (2001c) Winter stem pressures in walnut trees: effects of carbohydrates, cooling and freezing. Tree Physiol 21:387-394

Améglio T, Bodet C, Lacointe A, Cochard H (2002) Winter embolism, mechanisms of xylem hydraulic conductivity recovery and springtime growth patterns in walnut and peach trees. Tree Physiol 22:1211-1220

Améglio T, Decourteix M, Alves G, Valentin V, Sakr S, Julien J-L, Pétel G, Guilliot A, Laco A (2004) Temperature effects on xylem sap osmolarity in walnut trees: evidence for a vitalistic model of winter embolism repair. Tree Physiol 24:785-793

Baker FS (1948) A revised tolerance table. J For 45:179-181

Baldocchi D, Wong S (2008) Accumulated winter chill is decreasing in the fruit growing regions of California. Clim Chang 87:153166

Bonhomme M, Peuch M, Améglio T, Rageau R, Guilliot A, Decourteix M, Alves G, Sakr S, Lacointe A (2010) Carbohydrate uptake from xylem vessels and its distribution among stem tissues and buds in walnut (Juglans regia $\mathrm{L}$ ). Tree Physiol 30:89-102

Bréda N, Huc R, Granier A, Dreyer E (2006) Temperate forest trees and stands under severe drought: a review of ecophysiological responses, adaptation processes and long-term consequences. Ann For Sci 63:625-644

Carpenter SB, Hanover JW (1974) Comparative growth and photosynthesis of black walnut and honeylocust seedlings. For Sci 20:317-324

Chenevard D, Frossard JS, Lacointe A (1994) Lipid utilization and carbohydrate partitioning during germination of English walnut (Juglans regia). Ann For Sci 51:373-379

Chenevard D, Frossard JS, Jay-Allemand C (1997) Carbohydrate reserves and $\mathrm{CO}_{2}$ balance of hybrid walnut (Juglans nigra no. $23 \times$ Juglans regia) plantlets during acclimatization. Sci Hort 68:207-217

Christensen JH, Hewitson B, Busuioc A, Chen A, Gao X, Held I, Jones R, Kolli RK, Kwon W-T, Laprise R, Magaña Rueda V, Mearns L, Menéndez CG, Räisänen J, Rinke A, Sarr A, Whetton P (2007) Regional Climate Projections. In: Solomon S, Qin D, Manning M, Chen Z, Marquis M, Averyt KB, Tignor M, Miller HL (eds) Climate change 2007: The physical science basis. Contribution of Working Group I to the Fourth Assessment Report of the Intergovernmental Panel on Climate Change. Cambridge University Press, Cambridge, pp 847-940

Cochard H, Lemoine D, Améglio T, Granier A (2001) Mechanisms of xylem recovery from winter embolism in Fagus sylvatica. Tree Physiol 21:27-33

Cochard H, Coll L, Le Roux X, Améglio T (2002) Unraveling the effects of plant hydraulics on stomatal closure during water stress in walnut. Plant Physiol 128:282-290 
Cochard H, Venisse J-S, Barigah TS, Brunel N, Herbette S, Guilliot A, Tyree MT, Sakr S (2007) Putative role of aquaporins in variable hydraulic conductance of leaves in response to light. Plant Physiol 143:122-133

Crepinsek Z, Solar M, Stampar F, Solar A (2009) Shifts in walnut (Juglans regia L.) phenology due to increasing temperatures in Slovenia. J Hort Sci Biotech 84:59-64

Daudet F-A, Le Roux X, Sinoquet H, Adam B (1999) Wind speed and leaf boundary layer conductance variation within tree crownconsequences on leaf-to-atmosphere coupling and tree functions. Agric For Meteorol 97:171-187

Davies WJ, Kozlowski TT (1977) Variations among woody plants in stomatal conductance and photosynthesis during and after drought. Plant Soil 46:435-444

Dean TJ, Pallardy SG, Cox GS (1982) Photosynthetic responses of black walnut (Juglans nigra) to shading. Can J For Res 12:725730

Decourteix M, Alves G, Brunel N, Améglio T, Guilliot A, Lemoine R, Pétel G, Sakr S (2006) JrSUT1, a putative xylem sucrose transporter, could mediate sucrose influx into xylem parenchyma cells and be upregulated by freeze-thaw cycles over the autumnwinter period in walnut tree (Juglans regia L). Plant Cell Environ 29:36-47

Decourteix M, Alves G, Bonhomme M, Peuch M, Baaziz KB, Brunel N, Guilliot A, Rageau R, Améglio T, Pétel G, Sakr S (2008) Sucrose (JrSUT1) and hexoses (JrHT1 and 2) transporters in walnut xylem parenchyma cells: their potential role in early events of growth resumption. Tree Physiol 28:215-224

Delaire M, Frak E, Sigogne M, Adam B, Beaujard F, Le Roux X (2005) Sudden increase in atmospheric $\mathrm{CO}_{2}$ concentration reveals strong coupling between shoot carbon uptake and root nutrient uptake in young walnut trees. Tree Physiol 25:229-235

Deng X, Weinbaum SA, DeJong TM (1989) Use of labeled nitrogen to monitor transition in nitrogen dependence from storage to current-year uptake in mature walnut trees. Trees 3:11-16

Dreyer E, Le Roux X, Montpied P, Daudet F-A, Masson F (2001) Temperature response of leaf photosynthetic capacity in seedlings from seven temperate tree species. Tree Physiol 21:223-232

Dudek DM, McClenahen JR, Mitsch WJ (1998) Tree growth responses of Populus deltoides and Juglans nigra to streamflow and climate in a bottomland hardwood forest in central Ohio. Ame Mid Nat 140:233-244

Ewers FW, Améglio T, Cochard H, Beaujard F, Martignac M, Vandame M, Bodet C, Cruiziat P (2001) Seasonal variation in xylem pressure of walnut trees: root and stem pressures. Tree Physiol 21:1123-1132

Fady B, Duccy F, Aleta N, Becquey J, Diaz Vazquez R, Fernandez Lopez F, Jay-Allemand C, Lefèvre F, Ninot A, Panetsos K, Paris P, Pisanelli A, Rumpf H (2003) Walnut demonstrates strong genetic variability for adaptive and wood quality traits in a network of juvenile field tests across Europe. New For 25:211225

Frak E, Le Roux X, Millard P, Dreyer E, Jaouen G, Saint-Joanis B, Wendler R (2001) Changes in total leaf nitrogen and partitioning of leaf nitrogen drive photosynthetic adaptation to light in fully developed walnut leaves. Plant Cell Environ 24:1279-1288

Frak E, Le Roux X, Millard P, Adam B, Dreyer E, Escuit C, Sinoquet H, Vandame M, Varlet-Grancher C (2002a) Spatial distribution of leaf nitrogen and photosynthetic capacity within the foliage of individual trees: disentangling the effects of local light quality, leaf irradiance, and transpiration. J Exp Bot 53:2207-2216

Frak E, Millard P, Le Roux X, Guillaumie S, Wendler R (2002b) Coupling sap flow velocity and amino acid concentrations as an alternative method to ${ }^{15} \mathrm{~N}$ labeling for quantifying nitrogen remobilization by walnut trees. Plant Physiol 130:1043-1053
Frak E, Le Roux X, Millard P, Guillaumie S, Wendler R (2005) Nitrogen availability, local light regime and leaf rank effects on the amount and sources of $\mathrm{N}$ allocated within the foliage of young walnut (Juglans nigra $\times$ regia) trees. Tree Physiol 26:4349

Frossard JS, Lacointe A (1988) Les variations saisonnières de l'utilisation du carbone chez les arbres au stade végétatif, en zone tempérée. Bull Soc Bot Fr 135:9-24

Frossard JS, Charron A, Lacointe A (1989) Growth relationships between root and shoot in walnut seedlings (Juglans regia L.). Ann For Sci 46:297s-300s

Gauthier M-M, Jacobs DF (2009) Short-term physiological responses of black walnut (Juglans nigra $\mathrm{L}$ ) to plantation thinning. For Sci 55:221-229

Gauthier M-M, Jacobs DF (2010) Ecophysiological responses of black walnut (Juglans nigra) to plantation thinning along a vertical canopy gradient. For Ecol Manage 259:867-874

George MF, Hong SG, Burke MJ (1977) Cold hardiness and deep supercooling of hardwoods: its occurrence in provenance collections of red oak, yellow birch, black walnut, and black cherry. Ecol 58:674-680

Ginter-Whitehouse DL, Hinckley TM, Pallardy SG (1983) Spatial and temporal aspects of water relations of three tree species with different vascular anatomy. For Sci 29:317-329

Goldfarb D, Hendrick R, Pregitzer K (1990) Seasonal nitrogen and carbon concentrations in white, brown and woody fine roots of sugar maple (Acer saccharum Marsh). Plant Soil 126:144-148

Green SR (1993) Radiation balance, transpiration and photosynthesis of an isolated tree. Agric For Meteorol 64:201-221

Green DS, Kruger EL (2001) Light-mediated constraints on leaf function correlate with leaf structure among deciduous and evergreen tree species. Tree Physiol 21:1341-1346

Hardin JW, Leopold DJ, White FM (2001) Harlow \& Harrar's textbook of dendrology, 9th edn. McGraw Hill, New York

Hemery GE, Clark JR, Aldinger E, Claessens H, Malvolti ME, O'Connor E, Raftoyannis Y, Savill PS, Brus R (2010) Growing scattered broadleaved tree species in Europe in a changing climate: a review of risks and opportunities. For 83:65-81

Hinckley TM, Bruckerhoff DN (1975) The effects of drought on water relations and stem shrinkage of Quercus alba. Can J Bot 53:62-72

Hinckley TM, Dougherty PM, Lassoie JP, Roberts JE, Teskey RO (1979) A severe drought: impact on tree growth, phenology, net photosynthetic rate and water relations. Ame Mid Nat 102:307316

Huntington TG, Richardson AD, McGuire KJ, Hayhoe K (2009) Climate and hydrological changes in the northeastern United States: recent trends and implications for forested and aquatic systems. Can J For Res 39:199-212

Jacobs DF, Seifert JR (2004) Facilitating nutrient acquisition of black walnut and other hardwoods at plantation establishment. In: Michler CH, Pijut PM, Van Sambeek JW, Coggeshall MV, Seifert J, Woeste K, Overton R, Ponder F Jr (eds) Black walnut in a new century. Proceedings of the 6th Walnut Council Research Symposium, 25-28 July 2004, Lafayette, IN. USDA For Serv, Gen Tech Rep NC-243, St Paul, pp 66-70

Jacobs DF, Salifu KF, Seifert JR (2005) Growth and nutritional response of hardwood seedlings to controlled-release fertilization at outplanting. For Ecol Manage 214:28-39

King JS, Kubiske ME, Pregitzer KS, Hendrey GR, McDonald EP, Giardina CP, Quinn VS, Karnosky DF (2005) Tropospheric $\mathrm{O}_{3}$ compromises net primary production in young stands of trembling aspen, paper birch and sugar maple in response to elevated atmospheric $\mathrm{CO}_{2}$. New Phytol 168:623-636

Kozlowski TT, Pallardy SG (1997) Physiology of woody plants, 2nd edn. Academic Press, San Diego 
Kramer PJ (1983) Water relations of plants. Academic Press, New York

Kuhns MR, Garrett HE, Teskey RO, Hinckley TM (1985) Root growth of black walnut trees related to soil temperature, soil water potential, and leaf water potential. For Sci 31:617-629

Lacointe A (1989) Assimilate allocation and carbon reserves in Juglans regia L. seedlings. Ann For Sci 46:832s-836s

Lacointe A (2000) Carbon allocation among tree organs: a review of basic processes and representation in functional-structural tree models. Ann For Sci 57:521-533

Lacointe A, Kajji A, Améglio T, Daudet FA, Cruiziat P, Archer P, Frossard JS (1993) Storage and mobilization of carbon reserves in walnut and its consequences on the water status during dormancy. Acta Hort 311:201-209

Lacointe A, Kajji A, Daudet F-A, Archer P, Frossard J-S (1995) Seasonal variation of photosynthetic carbon flow rate into young walnut and its partitioning among the plant organs and functions. J Plant Physiol 146:222-230

Le Roux X, Grand S, Dreyer E, Daudet F-A (1999a) Parameterization and testing of a biochemically based photosynthesis model for walnut (Juglans regia) trees and seedlings. Tree Physiol 19:481492

Le Roux X, Sinoquet H, Vandame M (1999b) Spatial distribution of leaf dry weight per area and leaf nitrogen concentration in relation to local radiation regime within an isolated tree crown. Tree Physiol 19:181-188

Le Roux X, Bariac T, Sinoquet H, Genty B, Piel C, Mariotti A, Girardin C, Richard P (2001) Spatial distribution of leaf wateruse efficiency and carbon isotope discrimination within an isolated tree crown. Plant Cell Environ 24:1021-1032

Lechowicz MJ (1984) Why do temperate deciduous trees leaf out at different times? Adaptation and ecology of forest communities. Ame Nat 124:821-842

Lemprière TC, Bernier PY, Carroll AL, Flannigan MD, Gilsenan RP, McKenney DW, Hogg EH, Pedlar JH, Blain D (2008) The importance of forest sector adaptation to climate change. Nat Resour Can, Can For Serv, North For Cent, Edmonton, AB, Inf Rep NOR-X-416E

Lennon JM, Aber JD, Melillo JM (1985) Primary production and nitrogen allocation of field grown sugar maples in relation to nitrogen availability. Biogeochem 1:135-154

Lindner M, Maroschek M, Netherer S, Kremer A, Barbati A, GarciaGonzalo J, Seidl R, Delzon S, Corona P, Kolströma M, Lexer MJ, Marchetti M (2010) Climate change impacts, adaptive capacity, and vulnerability of European forest ecosystems. For Ecol Manage 259:698-709

Loach K (1967) Shade tolerance in tree seedlings. I Leaf photosynthesis and respiration in plants raised under artificial shade. New Phytol 66:607-621

Loacker K, Kofler W, Pagitz K, Oberhuber W (2007) Spread of walnut (Juglans regia L.) in an Alpine valley is correlated with climate warming. Flora 202:70-78

Loewenstein NJ, Pallardy SG (1998a) Drought tolerance, xylem sap abscisic acid and stomatal conductance during soil drying: a comparison of canopy trees of three temperate deciduous angiosperms. Tree Physiol 18:431-439

Loewenstein NJ, Pallardy SG (1998b) Drought tolerance, xylem sap abscisic acid and stomatal conductance during soil drying: a comparison of young plants of four temperate deciduous angiosperms. Tree Physiol 18:421-430

Loewenstein NJ, Pallardy SG (2002) Influence of a drying cycle on post-drought xylem sap abscisic acid and stomatal responses in young temperate deciduous angiosperms. New Phytol 156:351-361
Lucier AA, Hinckley TM (1982) Phenology, growth and water relations of irrigated and non-irrigated black walnut. For Ecol Manage 4:127-142

Luedeling E, Zhang M, McGranahan G, Leslie C (2009a) Validation of winter chill models using historic records of walnut phenology. Agric For Meteorol 149:1854-1864

Luedeling E, Gebauer J, Buerkert A (2009b) Climate change effects on winter chill for tree crops with chilling requirements on the Arabian Peninsula. Clim Chang 96:219-237

Luedeling E, Steinmann KP, Zhang M, Brown PH, Grant J, Girvetz EH (2011) Climate change effects on walnut pests in California. Global Change Biol 17:228-238

Maillard P, Deléens E, Daudet FA, Lacointe A, Frossard JS (1994a) Carbon economy in walnut seedlings during the acquisition of autotrophy studied by long-term labelling with ${ }^{13} \mathrm{CO}_{2}$. Physiol Plantarum 91:359-368

Maillard P, Deléens E, Daudet FA, Lacointe A, Frossard JS (1994b) Carbon and nitrogen partitioning in walnut seedlings during the acquisition of autotrophy through simultaneous ${ }^{13} \mathrm{CO}_{2}$ and ${ }^{15} \mathrm{NO}_{3}$ long-term labeling. J Exp Bot 45:203-210

Maillard P, Deléens E, Castell F, Daudet F-A (1999) Source-sink relationships for carbon and nitrogen during early growth of Juglans regia L seedlings: analysis at two elevated $\mathrm{CO}_{2}$ concentrations. Ann For Sci 56:59-69

Mapelli S, Lombardi L, Brambilla I, Lulini A, Bertani A (1997) Walnut plant selection to hypoxic soil resistance. Acta Hortic 442:129-136

Martin GC, Uriu K, Nishijima C (1980) The effect of drastic reduction of water input on mature walnut trees. Hort Sci 15:157-158

Martin U, Pallardy SG, Bahari ZA (1987) Dehydration tolerance of leaf tissues of six woody angiosperm species. Physiol Plantarum 69:182-186

McKenney DW, Pedlar JP, Iverson LR, Hutchinson MF, Lawrence K, Campbell K (2007) Potential impacts of climate change on the distribution of North American trees. Biosci 57:939-948

McLaughlin SB, Nosal M, Wullschleger SD, Sun G (2007a) Interactive effects of ozone and climate on tree growth and water use in a southern Appalachian forest in the USA. New Phytol 174:109-124

McLaughlin SB, Wullschleger SD, Sun G, Nosal M (2007b) Interactive effects of ozone and climate on water use, soil moisture content and streamflow in a southern Appalachian forest in the USA. New Phytol 174:125-136

Millard P, Grelet G-A (2010) Nitrogen storage and remobilization by trees: ecophysiological relevance in a changing world. Tree Physiol 30:1083-1095

Mohan JE, Cox RM, Iverson LR (2009) Composition and carbon dynamics of forests in northeastern North America in a future, warmer world. Can J For Res 39:213-230

Murray G, Byrnes WR (1975) Effect of night temperature on dehardening in black walnut seedlings. For Sci 21:313-317

Naidu SL, DeLucia EH (1997) Acclimation of shade-developed leaves on sapling exposed to late-season canopy gaps. Tree Physiol 17:367-376

Nakicenovic N, Alcamo J, Davis G, Vries Bd, Fenhann J, Gaffin S, Gregory K, Grübler A, Jung TY, Kram T, Rovere ELL, Michaelis L, Mori S, Morita T, Pepper W, Pitcher H, Price L, Riahi K, Roehrl A, Rogner H-H, Sankovski A, Schlesinger M, Shukla P, Smith S, Swart R, Rooijen Sv, Victor N, Dadi Z (2000) IPCC Special Report on Emissions Scenarios (SRES)

Ni B-R, Pallardy SG (1990) Response of liquid-flow resistance to soil drying in seedlings of four deciduous angiosperms. Oecologia $84: 260-264$

Ni B-R, Pallardy SG (1991) Response of gas exchange to water stress in seedlings of woody angiosperms. Tree Physiol 8:1-9 
Ni B-R, Pallardy SG (1992) Stomatal and nonstomatal limitations to net photosynthesis in seedlings of woody angiosperms. Plant Physiol 99:1502-1508

Nicodemus MA, Salifu KF, Jacobs DF (2008a) Nitrate reductase activity and nitrogen compounds in xylem exudate of Juglans nigra seedlings: relation to nitrogen source and supply. Trees 22:685-695

Nicodemus MA, Salifu KF, Jacobs DF (2008b) Growth, nutrition, and photosynthetic response of black walnut to varying nitrogen sources and rates. J Plant Nutr 31:1917-1936

Niinemets U (2007) Photosynthesis and resource distribution through plant canopies. Cell Plant Environ 30:1052-1071

Norby RJ, DeLucia EH, Gielen B, Calfapietra C, Giardina CP, King JS, Ledford J, McCarthy HR, Moore DJP, Ceulemans R, De Angelis P, Finzi AC, Karnosky DF, Kubiske ME, Lukac M, Pregitzer KS, Scarascia-Mugnozza GE, Schlesinger WH, Oren R (2005) Forest response to elevated $\mathrm{CO}_{2}$ is conserved across a broad range of productivity. Proc Natl Acad Sci USA 102:18052-18056

Norby RJ, Warren JM, Iversen CM, Medlyn BE, McMurtrie RE (2010) $\mathrm{CO}_{2}$ enhancement of forest productivity constrained by limited nitrogen availability. Proc Natl Acad Sci USA 107:19368-19373

Pallardy SG, Rhoads JL (1993) Morphological adaptations to drought in seedlings of deciduous angiosperms. Can J For Res 23:17661774

Parker WC, Pallardy SG (1985a) Drought-induced leaf abscission and whole-plant drought tolerance of seedlings of seven black walnut families. Can J For Res 15:818-821

Parker WC, Pallardy SG (1985b) Genotypic variation in tissue water relations of leaves and roots of black walnut (Juglans nigra) seedlings. Physiol Plantarum 64:105-110

Parker WC, Pallardy SG (1991) Gas exchange during a soil drying cycle in seedlings of four black walnut (Juglans nigra L) families. Tree Physiol 9:339-348

Paschke MW, Dawson JO, David MB (1989) Soil nitrogen mineralization in plantations of Juglans nigra interplanted with actinorhizal Elaeagnus umbellata or Alnus glutinosa. Plant Soil 118:33-42

Picon-Cochard C, Nsourou-Obame A, Collet C, Guehl J-M, Ferhi A (2001) Competition for water between walnut seedlings (Juglans regia) and rye grass (Lolium perenne) assessed by carbon isotope discrimination and $\delta^{18} \mathrm{O}$ enrichment. Tree Physiol 21:183-191

Piel C, Frak E, Le Roux X, Genty B (2002) Effect of local irradiance on $\mathrm{CO}_{2}$ transfer conductance of mesophyll in walnut. J Exp Bot $53: 2423-2430$

Poirier M, Lacointe A, Améglio T (2010) A semi-physiological model of cold hardening and dehardening in walnut stem. Tree Physiol 30:1555-1569

Ponder F Jr (1998) Fertilizer combinations benefit diameter growth of plantation black walnut. J Plant Nutr 21:1329-1337

Rosati A, Metcalf SG, Lampinen BD (2004) A simple method to estimate photosynthetic radiation use efficiency of canopies. Ann Bot 93:567-574

Sakr S, Alves G, Morillon R, Maurel K, Decourteix M, Guilliot A, Fleurat-Lessard P, Julien J-L, Chrispeels MJ (2003) Plasma membrane aquaporins are involved in winter embolism recovery in walnut tree. Plant Physiol 133:630-641

Salifu KF, Jacobs DF, Pardillo G, Schott M (2006) Response of grafted Juglans nigra to increasing nutrient availability: growth, nutrition, and nutrient retention in root plugs. HortSci 41:1477-1480
Salifu KF, Apostol KG, Jacobs DF, Islam MA (2008) Growth, physiology, and nutrient retranslocation in nitrogen-15 fertilized Quercus rubra seedlings. Ann For Sci 65:1-8

Salifu KF, Islam MA, Jacobs DF (2009) Retranslocation, plant, and soil recovery of nitrogen-15 applied to bareroot black walnut seedlings. Commun Soil Sci Plant Anal 40:1408-1417

Schlesinger RC, Funk DT (1977) Manager's handbook for black walnut. USDA For Serv Gen Tech Rep NC-GTR-38. USDA Forest Service, St Paul

Sinoquet H, Le Roux X, Adam B, Améglio T, Daudet F-A (2001) RATP: a model for simulating the spatial distribution of radiation absorption, transpiration and photosynthesis within canopies: application to an isolated tree crown. Plant Cell Environ 24:395406

Smith CC, Follmer D (1972) Food preferences of squirrels. Ecol 53:82-91

Sperry JS, Nichols KL, Sullivan JEM, Eastlack SE (1994) Xylem embolism in ring-porous, diffuse-porous, and coniferous trees of northern Utah and interior Alaska. Ecol 75:1736-1752

Thompson GW, McComb AL (1962) Growth of plantation black walnut in relation to $\mathrm{pH}$ and certain chemical factors of the soil. For Sci 8:322-333

Tinus RW (1976) Photoperiod and atmospheric $\mathrm{CO}_{2}$ level interact to control black walnut (Juglans nigra L.) seedling growth. Plant Physiol 57:106

Tyree MT, Cochard H (1996) Summer and winter embolism in oak: impact on water relations. Ann For Sci 53:163-170

Tyree MT, Cochard H, Cruiziat P, Sinclair B, Améglio T (1993) Drought-induced leaf shedding in walnut: evidence for vulnerability segmentation. Plant Cell Environ 16:879-882

United States Department of Agriculture (USDA) (2009) Summary of California County Commissioner's reports 2007-2008. USDA, Sacramento

Warren JM, Norby RJ, Wullschleger SD (2011) Elevated $\mathrm{CO}_{2}$ enhances leaf senescence during extreme drought in a temperate forest. Tree Physiol 31:117-130

Weinbaum S, Van Kessel C (1998) Quantitative estimates of uptake and internal cycling of ${ }^{14} \mathrm{~N}$-labeled fertilizer in mature walnut trees. Tree Physiol 18:795-801

Weinbaum SA, Muraoka TT, Plant RE (1994) Intracanopy variation in nitrogen cycling through leaves is influenced by irradiance and proximity to developing fruit in mature walnut trees. Trees 9:611

Williams RD (1990) Black walnut (Juglans nigra L). In: Burns RM, Honkala BM (eds) Silvics of North America, volume 2hardwoods. USDA Forest Service, Washington, DC, pp 391-399

Winter M-B, Wolff B, Gottschling H, Cherubini P (2009) The impact of climate on radial growth and nut production of Persian walnut (Juglans regia L) in Southern Kyrgyzstan. Eur J For Res 128:531-542

Wullschleger SD (1993) Biochemical limitations to carbon assimilation in $C_{3}$ plants - a retrospective analysis of the $A / C_{i}$ curves from 109 species. J Exp Bot 44:907-920

Wullschleger SD, Post WM, King AW (1995) On the potential for a $\mathrm{CO}_{2}$ fertilization effect in forests: estimates of the biotic growth factors based on 58-controlled exposure studies. In: Woodwell GM, Mackenzie FT (eds) Biotic feedbacks in the global biotic system: will the warming feed the warming? Oxford University Press, Oxford, pp 85-108 